\title{
EFFECTS OF SULPHITING AND OSM OTIC PRE-TREATMENTS ON THE EFFECTIVE MOISTURE DIFFUSION COEFFICIENTS DEFF OF AIR DRYING OF PINEAPPLE SLICES
}

$$
\mathrm{K} \operatorname{arim} O \mathrm{R}^{* 1}
$$

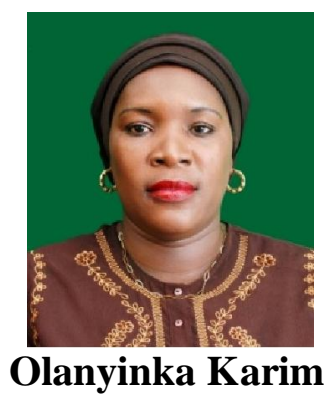

*Corresponding author email: olayinkakarim@yahoo.com

${ }^{1}$ Department of Home Economics and Food Science, University of Ilorin, Ilorin, Nigeria 


\section{ABSTRACT}

Air dehydration of fruits has been reported to be limiting in some factors especially on the drying kinetics and quality of the dried fruits. Removal of moisture during drying is attributed to these. This study was designed to evaluate the effects of sulphiting and osmotic pretreatments on effective diffusion coefficient $\left(\mathrm{D}_{\text {eff }}\right)$ of air drying pineapple slices at $50^{\circ}$ and $70{ }^{\circ} \mathrm{C}$ temperatures. Smooth cayenne pineapple obtained from Ajanla farms, Ibadan, Nigeria was used for the study. The fruits were hand peeled and sliced to spherical slices of $5 \mathrm{~cm}$ radius and $0.5 \mathrm{~cm}$ thickness. Pineapple fruit slices were pretreated at three levels of sulphiting and sucrose/osmosis and two conditions of drying $\left(50{ }^{\circ} \mathrm{C}\right.$ at $16 \mathrm{~h}$ and $70{ }^{\circ} \mathrm{C}$ at $\left.10 \mathrm{~h}\right)$, resulting in 18 treatments in a factorial experimental design. Changes in moisture were monitored hourly and Fick's second law was used to describe the rate of moisture transfer to determine the $D_{\text {eff }}$ as the slices were dried using a cabinet dryer. Results showed that the $\mathrm{D}_{\text {eff }}$ was strongly affected by sulphiting at 2500 ppm equalling $9.10 \pm 0.13 \times 10^{-6}$ and $6.78+0.53 \times 10^{-}$ ${ }^{6} \mathrm{~cm} / \mathrm{s}$ for $70{ }^{\circ} \mathrm{C}$ and $50{ }^{\circ} \mathrm{C}$ drying temperatures, respectively. The osmotic pretreatment at $40 \%$ sucrose recorded $4.91 \pm 0.15 \times 10^{-6} \mathrm{~cm} / \mathrm{s}$ and $6.93 \pm 0.03 \times 10^{-}$ ${ }^{6} \mathrm{~cm} / \mathrm{s}$ for $70{ }^{\circ} \mathrm{C}$ and $50{ }^{\circ} \mathrm{C}$ drying temperature respectively. The control samples had $3.14 \pm 0.23 \times 10^{-6}$ and $4.19 \pm 0.21 \times 10^{-6}$ at $70{ }^{\circ} \mathrm{C}$ and $50{ }^{\circ} \mathrm{C}$ drying temperature, respectively. The high values obtained from the pretreated samples may be due to the restructuring of the cell walls. The combination of sulphiting and osmotic pretreatments also exhibited significant impact on the $\mathrm{D}_{\text {eff }}$ value, ranging between 5.13 to $8.42 \times 10^{-6}$, though not as pronounced as with the single pretreatment method. Furthermore, drying at $70{ }^{\circ} \mathrm{C}$ influenced the $\mathrm{D}_{\text {eff }}$ value more than drying at $50{ }^{\circ} \mathrm{C}$ with both pretreatment methods. The study, therefore, showed that pretreatment methods improved the $\mathrm{D}_{\text {eff }}$ of the pineapple slices, with the sulphiting pretreatment at 2500 ppm having the highest value.

K ey words: Sulphiting, osmotic, pretreatment, drying, kinetics 


\section{INTRODUCTION}

Air dehydration of fruits reportedly affects the quality of the dried fruits, though the method has been suggested as a way of developing dry fruit to alleviate huge fruit losses after harvesting [1,2]. Furthermore, the process has reportedly affected the rate of heat and mass transfer, which consequently affects the quality of the dried fruits $[1,2]$. The deterioration of quality is nutritional, physical and chemical in nature $[3,4,5]$.

The rate of drying is determined by the rates heat energy transfers to the material to provide the latent heat, though, under some circumstances the rate of mass transfer (removal of the water/or the $\mathrm{D}_{\text {eff }}$ ) can be limiting. This mostly depends on the nature of the food. With possible exception of freeze drying, animal and vegetable tissues undergo some amount of shrinkage during drying, especially at the later stage of drying [6]. A hard impermeable skin often forms on the surface usually causing lower drying rates [7]. This is called case hardening. The mechanisms of case hardening are not fully understood, because they are probably influenced by a number of factors, including migration of soluble solids to the surface and high surface temperature, towards the end of drying process, resulting in complex physical and chemical changes in the surface layer $[1,8,9]$.

Drying temperature is of more importance, mostly regarding the substantial effect it has on the texture of fruits. In general, rapid drying and high temperature cause greater changes than do moderate rates of drying and lower temperatures. High air drying temperature causes complex chemical and physical changes to the surface, and the formation of a hard impermeable skin, which also affects the rate of drying [9, $10]$.

Alteration of food cell structure prior to drying could influence the drying rate and consequently the dried product quality. Different pretreatment methods have been reported like sulphiting and osmotic pretreatment to alleviate some of these problems $[1,4,11,12,13,14,15]$. Sulphur dioxide, which possesses antimicrobial properties and inhibits enzymatic and non-enzymatic darkening, was found to be useful for controlling browning of cut fruits during drying. Reports also indicate that the rate of moisture removal during drying of fruits is affected by these pretreatment methods $[11,13,15,16]$, like the possible effect of $\mathrm{S}_{2}$ on the pectolytic enzyme activity, which consequently affects the textural property of the fruit [1]. On the other hand, the effect of osmotic dehydration prior to convectional drying on the rate of moisture transport and product, show that moisture content in sugar beet root decreased as the sucrose content increased [17]. A similar report was also obtained for carrot slices with and without osmotic treatment when drying rates were expressed as a function of the original sample solids, concluding the uptake of solid in the osmosis process, though the report did not reflect the $\mathrm{D}_{\text {eff }}$ values for both types of carrot slices [15]. On the other hand, Mazza [1] observed that as the concentration of sucrose used for dipping carrot cubes was increased from 5-60\%, the rate of moisture transport decreased, attributing to the depression of water vapour pressure in the product. Also, it applied to the crystallization of dissolved sugar impaired diffusion of water vapour 
and the rate of heat transfer.

Reports show that the influence of sulphiting and osmotic pretreatments on $\mathrm{D}_{\text {eff }}$ differs widely as the tissue properties change from one foodstuff to another with Fick's law being applied. More so, the combination of these pretreatment methods may pose a different result on the rate of moisture removal on fruit like pineapple. Effect of drying temperature was also noted [8]. This study was, therefore, developed to assess the influence of pretreatment methods (sulphiting and osmotic) on $\mathrm{D}_{\text {eff }}$ during dehydration of pineapple slices at $50{ }^{\circ} \mathrm{C}$ and $70{ }^{\circ} \mathrm{C}$.

\section{MATERIALSAND METHODS}

\section{M aterials}

Freshly harvested pineapple fruit (Ananas comosus L.) with good physiological maturity obtained from Ajanla farm, Ibadan, was used for the study. They were kept at $18{ }^{\circ} \mathrm{C}$ and $80-90 \%$ relative humidity up to the time of use, $48 \mathrm{~h}$ after arrival at the laboratory.

\section{Experimental Design}

A factorial experimental design was used. The factors were three levels of each of two pretreatment methods, sulphiting and sucrose - osmosis, and two levels of drying conditions (temperature/time) viz $70{ }^{\circ} \mathrm{C}$ for $10 \mathrm{~h}$ and $50{ }^{\circ} \mathrm{C}$ for $16 \mathrm{~h}$. This resulted in ( $3 \times 3 \times 2$ factorial experiment) 18 samples for the study. The experimental ranges of factors (Table 1) were established from preliminary experiments [11, 12].

\section{Sample preparation}

Fresh pineapple fruits selected with similar characteristics of ripening were hand peeled, cored, sliced and cut into spherical shape of $5 \mathrm{~mm}$ thickness and $20 \mathrm{~cm}$ radius. A batch of $5 \mathrm{~kg}$ of pineapple slices was pretreated with sucrose solution and/or sulphited as shown in Table 1.

Pineapple slices were osmotically treated by immersing in aqueous solution of $40 \%$ $\mathrm{w} / \mathrm{w}$ or $60 \% \mathrm{w} / \mathrm{w}$ of sucrose (Food grade of $98 \%$ purity) for $10 \mathrm{~min}$ at room temperature. The samples were drained on wire mesh and reweighed. The sulphiting pretreatment was done by dipping pineapple slices in $1500 \mathrm{ppm}$ and $2500 \mathrm{ppm} \mathrm{S} \mathrm{S}_{2}$ solution made from potassium meta bisulphate (KMS) solution for $6 \mathrm{~min}$ at room temperature, drained on wire mesh and reweighed.

Pretreated pineapple slices were dried in a cabinet dryer (Gallenkamp hot box, Manufactured by Gallenkamp, Riley Industry Limited, United Kingdom, Model No:13426E-24). The slices were spread on perforated stainless steel trays, of $1 \mathrm{~kg}$ pineapple slices. Tray loading and drying was done at $1.2 \mathrm{~m} / \mathrm{s}$ per square metre tray area with through air flow. All the 18 samples were dried simultaneously in order to ensure uniform drying conditions. As drying progressed, the moisture content of dehydrated slices was determined by standard hot air oven method at every hour [18]. At the end of drying, the final product weight was recorded and its moisture content 
determined. The weight changes recorded during drying was used in calculating moisture in percentage dry weight basis and drying rate as a function of weight loss per unit dry matter per drying hours, respectively.

The method of Bruin and Luyben [8] was used to monitor the kinetics of moisture transport to obtain the $D_{\text {eff. }}$ The volume of each pineapple slice $(v)$ was measured using a pycnometer (Cole-Parmer Pycnometer) (with water as the fluid) and the equivalent spherical radius ( $\mathrm{Re}$ ) was then calculated from the formula for the volume of sphere $\left(\mathrm{V}=4 \pi \mathrm{R}^{3} \mathrm{e} / 3\right)$ using the pineapple slice volume. It was assumed that the internal temperature of the fruit is uniform due to the low Biot number for heat transfer. Thus,

$$
\text { Bo }=h^{\mathrm{R}} / \mathrm{K}
$$

where $\mathrm{h}=$ heat transfer coefficient

is usually found for convectional air drying of foods $[13,19]$. The process was assumed to be isothermal; therefore, the heat transfer effects were neglected and Fick's second law was used to describe the rate of moisture transfer during the first falling period of drying. However, the pineapple slices did not have a spherical shape. The diffusion problem for any geometry can be reduced to the analytical solution corresponding to a sphere, by modifying the

Fourier Number, Fo $=D_{\text {eff }} t /{ }_{R}^{2}$

The expression of Fick's law for diffusion out of a sphere with boundary conditions of internal resistance controlling integrated over the volume of the sphere is

$$
M=\underset{m_{O}-m_{e}}{m-m_{e}} \quad \stackrel{n}{n} \quad \text { Bn exp }\left(-\mu^{2} n \text { Fo }\right)
$$

where, $B n=6 \mu^{2} \mu_{n}=n \pi$

Fo $=D_{\text {eff }} \mathrm{t} / \mathrm{R}^{2} \mathrm{e}$

$\mathrm{n}=1,2,3, \ldots \ldots \ldots$

$\mathrm{t}=$ time

mo $=$ uniform initial moisture content

me $=$ equilibrium moisture content

$\mathrm{Re}=$ sphere radius

$\mathrm{D}_{\text {eff }}=$ effective moisture diffusivity

The values of the effective diffusion coefficients $\mathrm{D}_{\text {eff }}$ (corrected by the shape factor) were calculated. The significance of the differences among the obtained $\mathrm{D}_{\text {eff }}$ values was analysed through a t parameter test with a $95 \%$ confidence level. 


\section{Statistical Analysis}

All statistical analyses were performed using the Statistical Analysis System [20]. Mean separation was obtained by Duncan Multiple Range test and Analysis of variance, ANOVA, was conducted on the mean values to determine the significance of any difference between samples [21].

\section{RESULTS}

The drying kinetics curves in Figures 1- 6 show drying rates versus drying time at 50 ${ }^{\circ} \mathrm{C}$ and $70{ }^{\circ} \mathrm{C}$ temperature. The drying rate on dry basis (DB) is plotted versus time $\mathrm{t}$, for all the samples. All the samples exhibited unsystematic drying rates, which revealed a typical behavior of drying of biological materials. Drying rates were higher with samples at $70{ }^{\circ} \mathrm{C}$ drying temperature, reflecting the influence of high temperature on drying. The sample sulphited with $2500 \mathrm{ppm} \mathrm{SO_{2 }}$ on Figures 3 and 4 had $0.42 \mathrm{~g}$ water $/ \mathrm{kg}$ dry matter $\mathrm{h}^{-1}$ at the $7^{\text {th }} \mathrm{h}$ and $0.78 \mathrm{~g}$ water $/ \mathrm{kg}$ dry matter $\mathrm{h}^{-1}$ at the $4^{\text {th }} \mathrm{h}$ of drying at $50{ }^{\circ} \mathrm{C}$ and $70{ }^{\circ} \mathrm{C}$ drying temperature, respectively. The control sample showd a close drying rate behavior to the two sulphited samples at $70{ }^{\circ} \mathrm{C}$ drying temperature while at $50{ }^{\circ} \mathrm{C}$ drying temperature, the control did not exhibit a sharp fall in drying rate like the other sulphited samples. The effect of sulphiting pretreatment was significant on the drying kinetics, declining with increase in drying time.

The combination of the pretreatments also affected the drying kinetics. The sample pretreated with $60 \%$ sucrose and $2500 \mathrm{ppm} \mathrm{SO}_{2}$ at the $5^{\text {th }} \mathrm{h}$ of drying recorded $0.51 \mathrm{~g}$ water $/ \mathrm{kg}$ dry matter $\mathrm{h}^{-1}$, while the average drying rate was $0.32 \mathrm{~g}$ water $/ \mathrm{kg}$ dry matter $\mathrm{h}^{-1}$ at $50{ }^{\circ} \mathrm{C}$ drying temperature in Figure 5. At $70{ }^{\circ} \mathrm{C}$ drying temperature, in Figure 6 , the average drying rate was $0.43 \mathrm{~g}$ water $/ \mathrm{kg}$ dry matter $\mathrm{h}^{-1}$, with the highest rate of water removal being $0.90 \mathrm{~g}$ water $/ \mathrm{kg}$ dry matter $\mathrm{h}^{-1}$.

Results of the $\mathrm{D}_{\text {eff }}$ are shown in Table 2, with significance differences at $95 \%$ confidence level, indicating the effects of pretreatment and drying variables on the rate of moisture transport. Sample pretreated with $2500 \mathrm{ppm} \mathrm{SO}_{2}$ at $70{ }^{\circ} \mathrm{C}$ drying temperature obtained the highest $D_{\text {eff }}$ with $9.10 \pm 0.13 \times 10^{-6} \mathrm{~cm}^{2} / \mathrm{s}$ while the control sample at $50{ }^{\circ} \mathrm{C}$ drying temperature had lowest value of $3.14 \pm 0.23 \times 10^{-6} \mathrm{~cm}^{2} / \mathrm{s}$. 


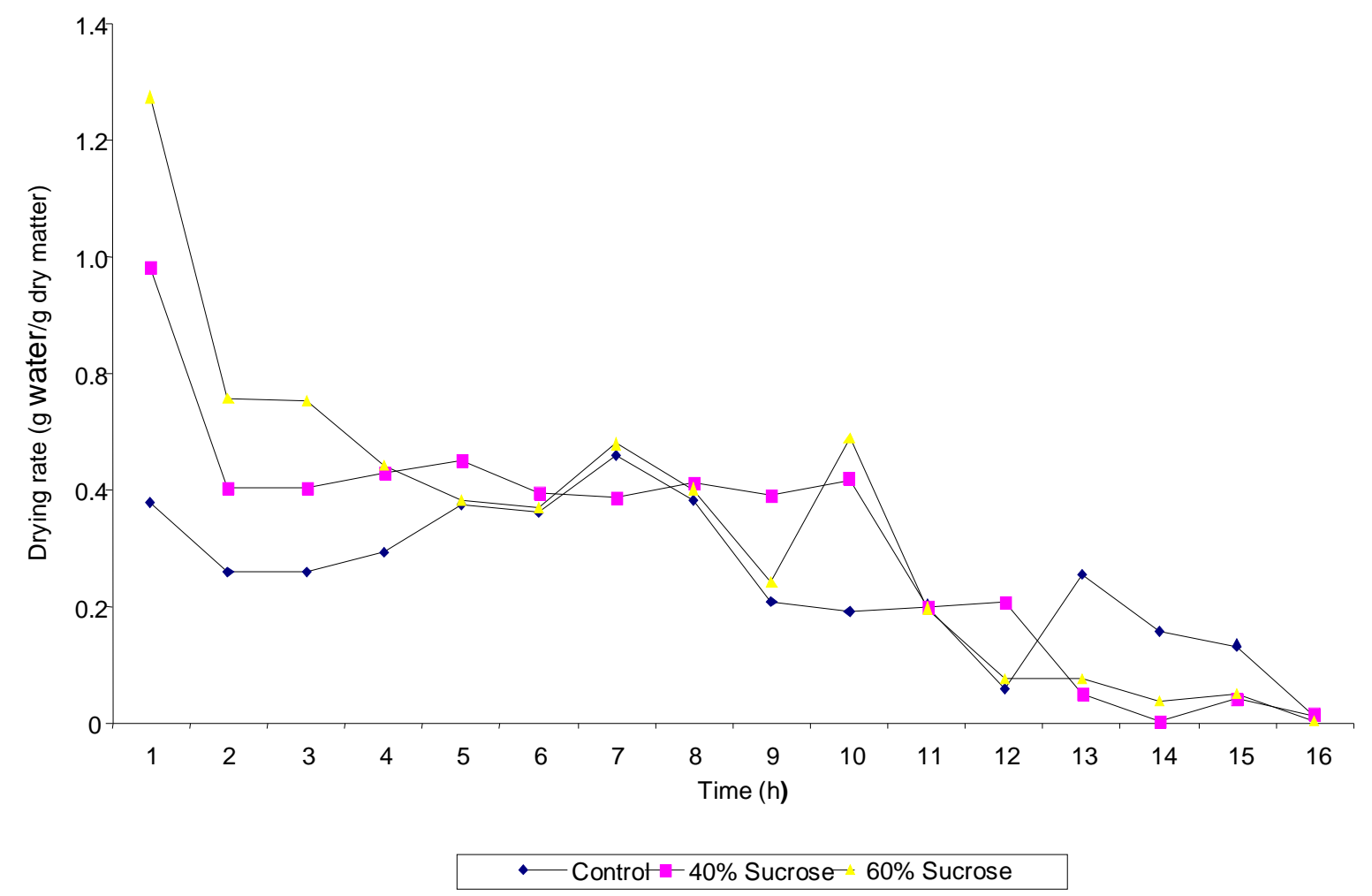

Figure 1: Effect of Sucrose pretreatment on drying rate of pineapple slices at 50 ${ }^{\circ} \mathrm{C}$ drying temperature 


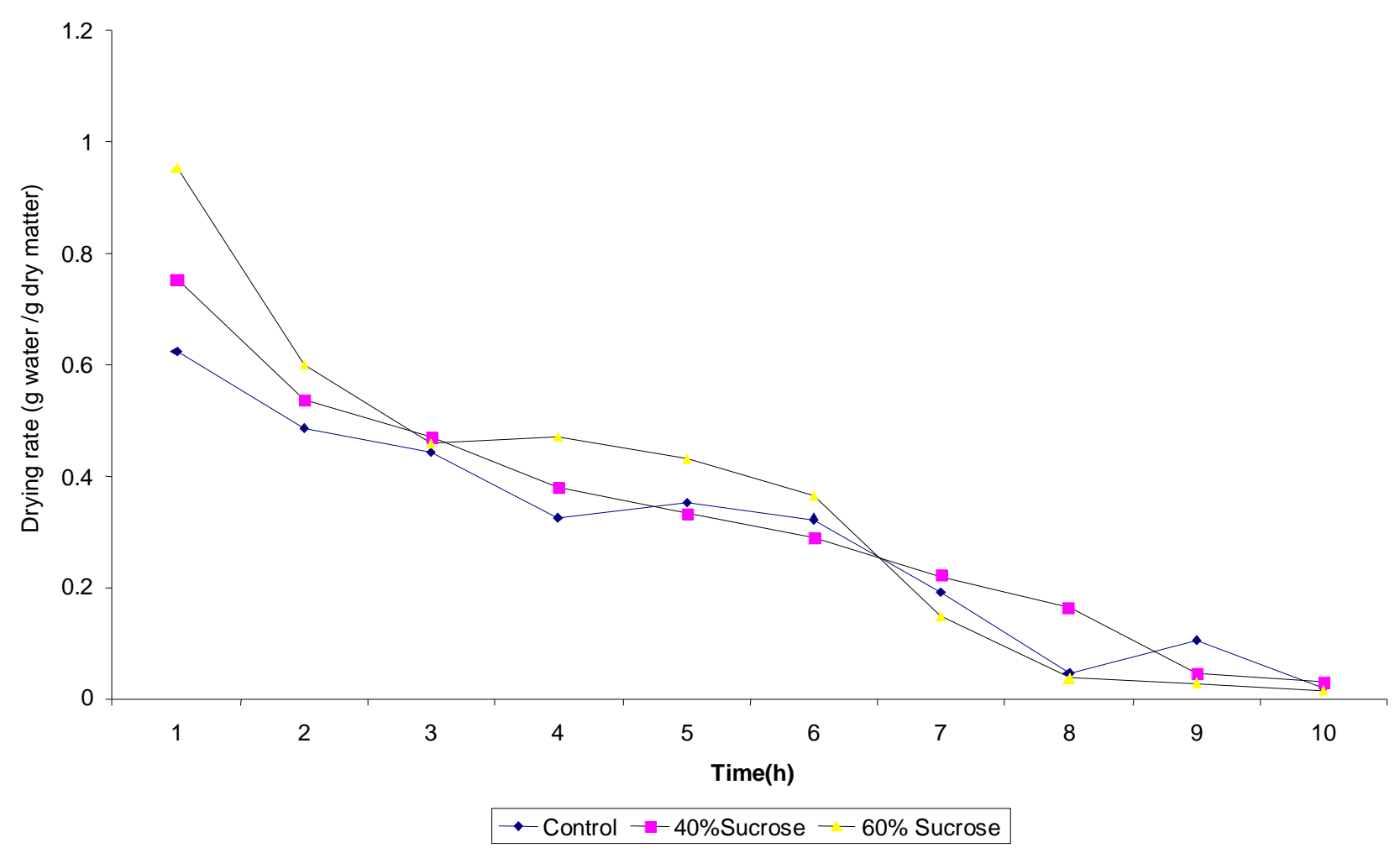

Figure 2: Effect of Sucrose pretreatment on drying rate of pineapple slices at 70 ${ }^{\circ} \mathrm{C}$ drying temperature 


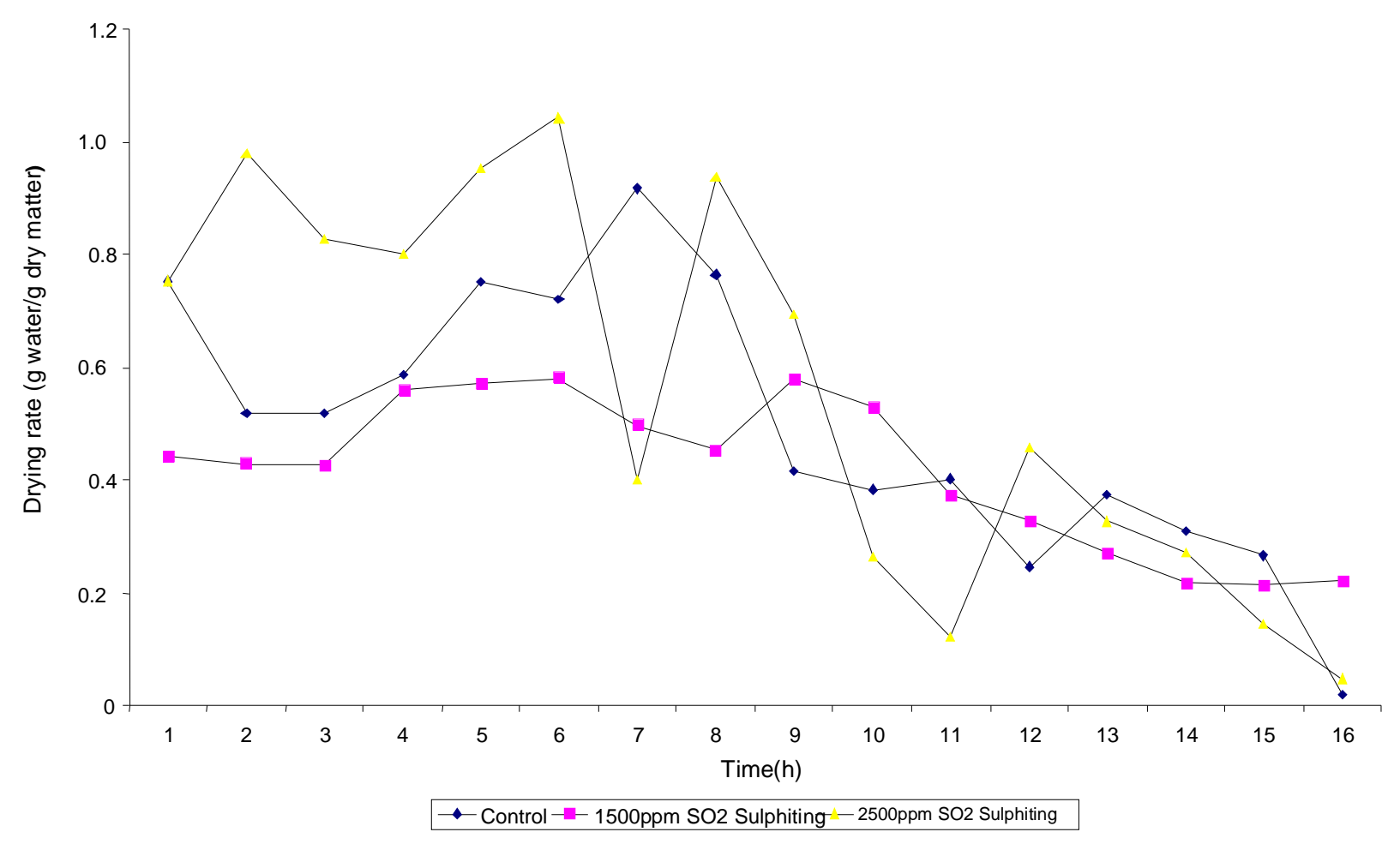

Figure 3: Effect of Sulphiting pretreatment on drying rate of pineapple slices at $50{ }^{\circ} \mathrm{C}$ drying temperature 


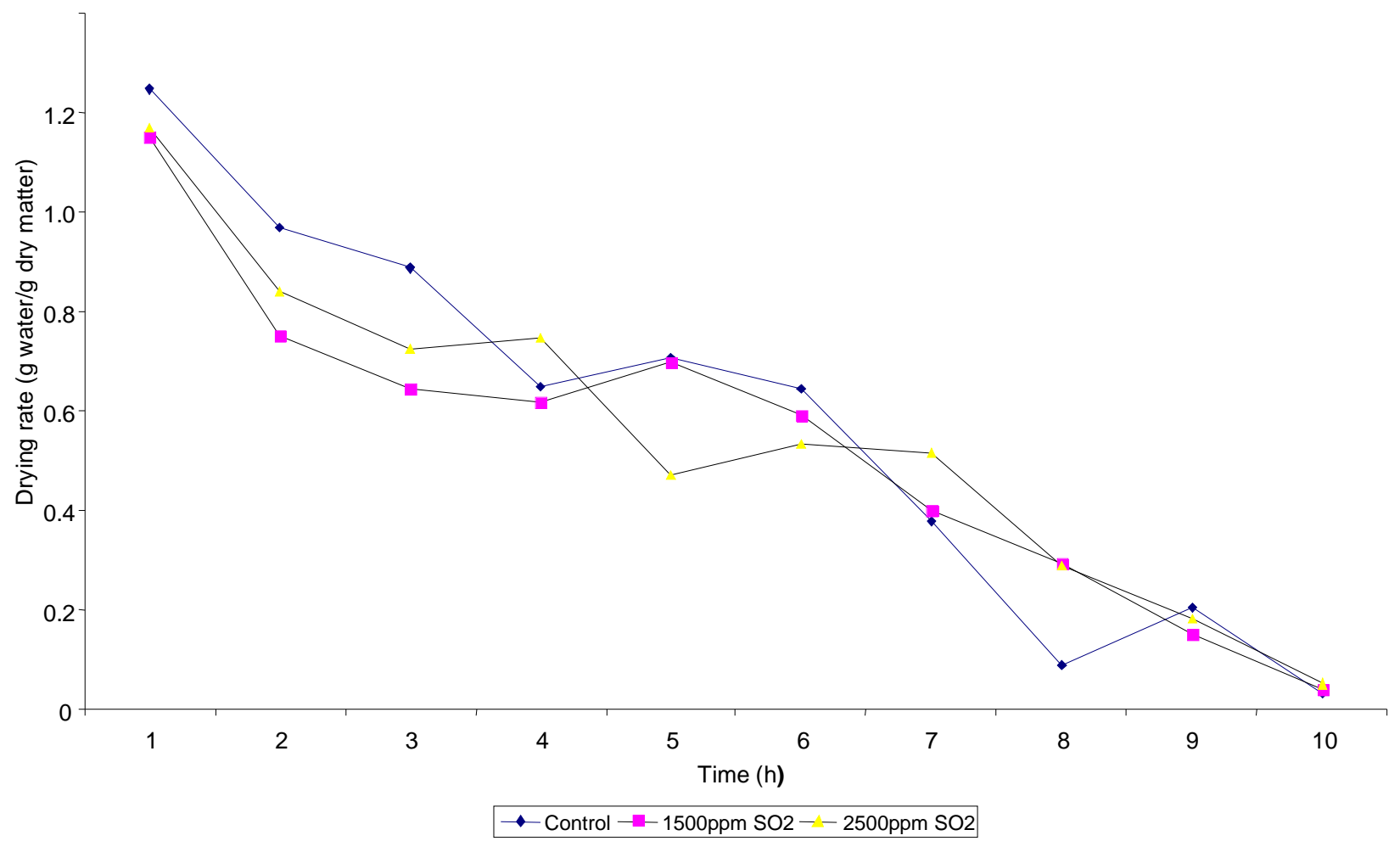

Figure 4: Effect of Sulphiting pretreatment on drying rate of pineapple slices at $70^{\circ} \mathrm{C}$ temperature 


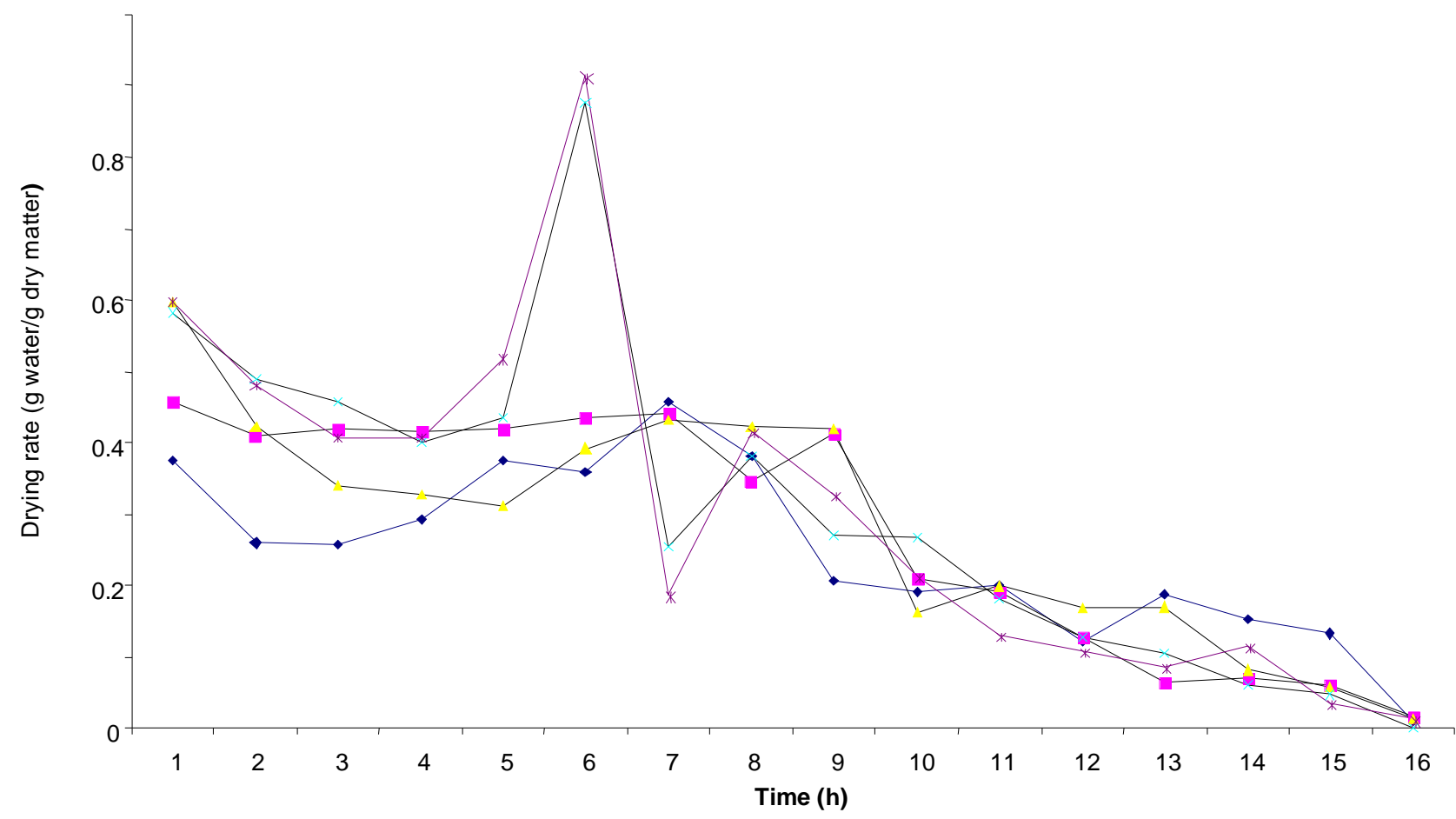

- Control - -40\%Sucrose /1500ppm SO2-40\%Sucrose /2500ppm SO2 -60\%Sucrose/1500ppm SO2*-60\%Sucrose/2500ppm SO2

Figure 5: Effect of Sucrose and Sulphiting pretreatments on drying rate of pineapple slices at $50^{\circ} \mathrm{C}$ drying temperature 


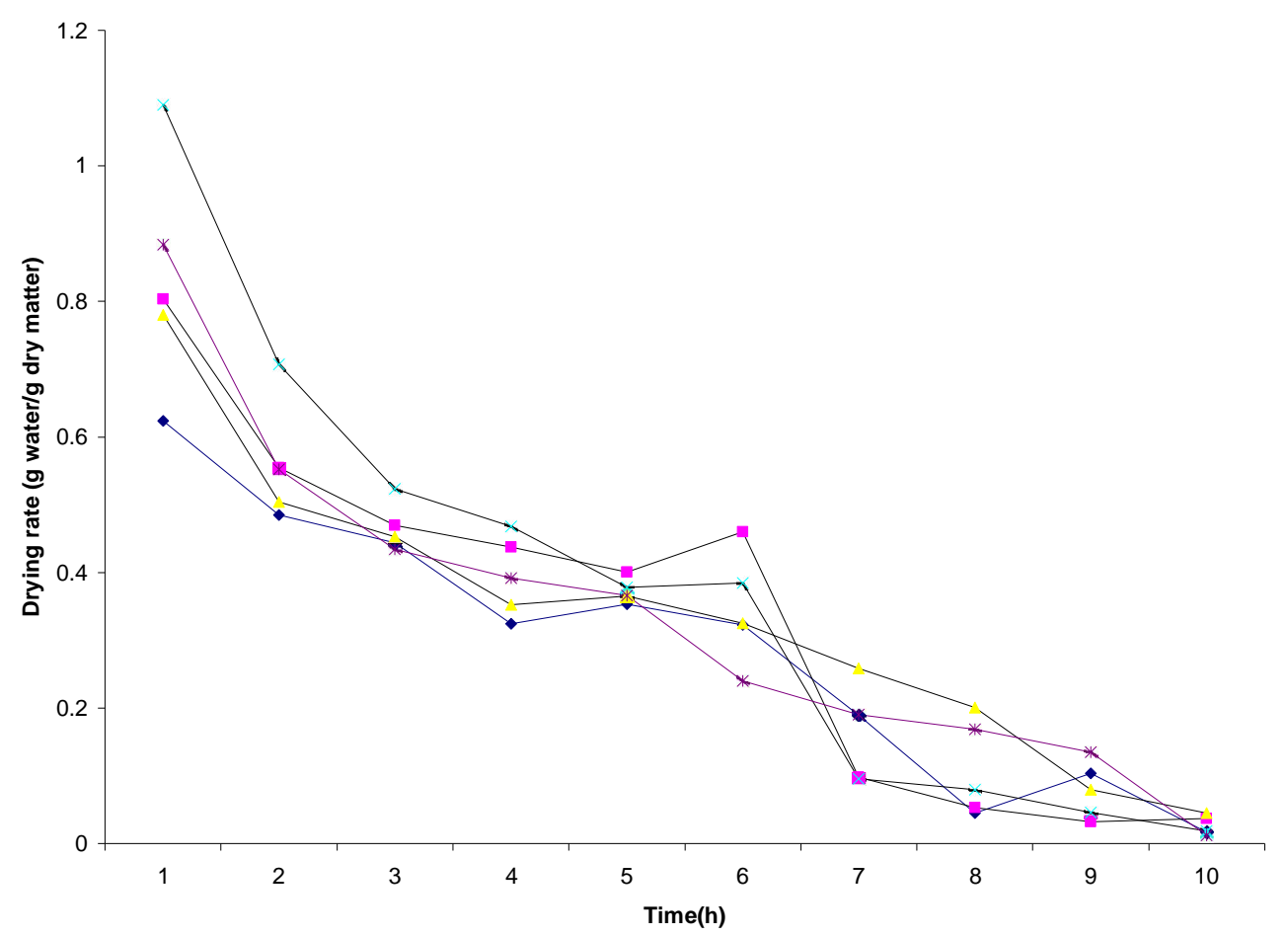

Control $--40 \%$ Sucrose /1500ppm SO2 - - 40\%Sucrose /2500ppm SO2 - -60\%Sucrose /1500ppm SO2 - *-60\%Sucrose /2500ppm SO2

Figure 6: Effect of Sucrose and Sulphiting pretreatments on drying rate of pineapple slices at $70^{\circ} \mathrm{C}$ drying temperature.

\section{DISCUSSION}

The unsystematic rate of drying of the samples revealed the influence of pretreatment methods on the permeability of the cell membranes, as well as their influence on the water binding capacity of the fibrous matter $[11,13]$. The observed sudden drop in moisture content during drying at $70{ }^{\circ} \mathrm{C}$ showed higher diffusive transfer of moisture to the evaporation surface compared to the samples dried at $50{ }^{\circ} \mathrm{C}$. The changes in the drying rates with no constant drying rate experienced were characteristic of most biological materials. According to Alvarez et al. [13], effects of blanching and sulphiting on the permeability of the cell membranes, as well as to their influence on the water binding capacities of the fibrous matter were responsible for the high rate of moisture removal observed with the samples. The variations in the intermediate values of water removal observed were probably caused by natural differences in the composition and structure of the raw pineapple slices, even at a uniform degree of ripeness and the variation of the pretreatment. The faster drying rate observed with samples dried at $70{ }^{\circ} \mathrm{C}$, shows relevance of temperature on drying. The relative lower moisture content recorded with combinations of pretreatment method also corroborates the $\mathrm{D}_{\text {eff }}$ values obtained. The observed faster drop in moisture content during drying at $70{ }^{\circ} \mathrm{C}$ showed higher diffusive transfer of moisture to the evaporation 
surface compared to the samples dried at $50{ }^{\circ} \mathrm{C}$. With appropriate control of air drying conditions, reduction of moisture content is possible at a rate dependent more in the air drying temperature and time. Ghaius et al. [18] also revealed the significant effects of time-temperature combination effect on convective drying of agricultural products.

It is apparent that drying rate decreases continuously with drying time. These results were in agreement with the earlier reports on food drying kinetics [22, 23, 24]. However, unlike the findings of Mazza [1] on effect of heat treatment on drying kinetics of fruits the obtained results showed that the pretreatment with $\mathrm{SO}_{2}$ influenced the drying kinetics than the sucrose osmotic pretreatment. This deviation might be due to the effect of $\mathrm{SO}_{2}$ pretreatment on physical and chemical changes on the water binding components of the pineapple slices and on the cellular membrane permeability.

All the pretreatment methods increased the $\mathrm{D}_{\text {eff }}$ significantly [17, 25]. The sulphiting pretreatment might have affected the permeability of cellular membrane of the slices, creating a faster drying rate at the two drying temperatures. Similarly, the osmotically pretreated samples exhibited high $\mathrm{D}_{\text {eff }}$ probably due to the severe ultra structural damage of the cell walls and solute uptake that increases water transport resistance and a reduces of the cell wall resistance. Furthermore, degradation of polysaccharides, and decrease in the amount of total pectin substances particularly the residual protopectin might have occurred during the osmosis process. This might have resulted in reduction of tensional and firmness of the slices, thereby causing an increase in $D_{\text {eff }}$ when compared to the control samples, as also observed by Heng et al., [26] on papaya. Such materials exhibit a reduced optical density, which is due to the fact that the binding force between the cell wall, and that the higher concentration of hydrozium ions present in the high acid fruits may accelerate the breakdown of the binding materials [13]. This also explains the possible degradation of polysaccharides as well as leaching of pectin and other cell wall soluble components.

\section{CONCLUSION}

Sulphiting and osmotic pretreatments influenced $\mathrm{D}_{\text {eff }}$ of pineapple slices at $50^{\circ} \mathrm{C}$ and $70^{\circ} \mathrm{C}$ drying temperatures. The combination of the two pretreatments affected the $\mathrm{D}_{\text {eff }}$ as compared to a single pretreatment method. The pretreated samples recorded a faster rate of moisture removal. Microscopic description of the product may explain the effect of the pretreatment methods on the cell structure and its influence on the $\mathrm{D}_{\text {eff }}$ value.

The study was self financed. 
Table 1: Factors and Levels of Experimental design for the study

\begin{tabular}{llll}
\hline Factors & \multicolumn{3}{l}{ L evels } \\
& 1 & 2 & 3 \\
\hline Sulphiting & O ppm & $1500 \mathrm{ppm}$ & $2500 \mathrm{ppm}$ \\
Sucrose/osmosis & $0 \%$ & $40 \%$ & $60 \%$ \\
Drying condition (Temperature/Time) & $70{ }^{\circ} \mathrm{C} / 10 \mathrm{~h}$ & $50{ }^{\circ} \mathrm{C} / 16 \mathrm{~h}$ & \\
\hline
\end{tabular}


Table 2: Effective Diffusion Coefficients $D_{\text {eff }}$ from Fick's Law on pretreated pineapple slices during drying

\begin{tabular}{|c|c|c|}
\hline Pretreatment & Drying temperature & $D_{\text {eff }} \times 10^{6}(\mathrm{~cm} 2 / \mathrm{s})$ \\
\hline Control & $50{ }^{\circ} \mathrm{C}$ & $3.14 \mathrm{a} \pm 0.23$ \\
\hline Control & $70{ }^{\circ} \mathrm{C}$ & $4.19 b \pm 0.21$ \\
\hline $40 \%$ sucrose & $50{ }^{\circ} \mathrm{C}$ & $4.91 b \pm 0.15$ \\
\hline $40 \%$ sucrose & $70{ }^{\circ} \mathrm{C}$ & $6.87 d \pm 0.18$ \\
\hline $60 \%$ sucrose & $50{ }^{\circ} \mathrm{C}$ & $5.89 c \pm 0.35$ \\
\hline $60 \%$ sucrose & $70{ }^{\circ} \mathrm{C}$ & $6.93 d \pm 0.63$ \\
\hline $1500 \mathrm{ppm} \mathrm{SO} \mathrm{S}_{2}$ & $50{ }^{\circ} \mathrm{C}$ & $6.12 \mathrm{c} \pm 0.41$ \\
\hline $1500 \mathrm{ppm} \mathrm{SO} \mathrm{S}_{2}$ & $70{ }^{\circ} \mathrm{C}$ & $8.24 c \pm 0.77$ \\
\hline $2500 \mathrm{ppm} \mathrm{SO} \mathrm{S}_{2}$ & $50{ }^{\circ} \mathrm{C}$ & $6.78 c \pm 0.53$ \\
\hline $2500 \mathrm{ppm} \mathrm{SO} \mathrm{S}_{2}$ & $70{ }^{\circ} \mathrm{C}$ & $9.10 f \pm 0.13$ \\
\hline $40 \%$ Sucrose $/ 1500 \mathrm{ppm} \mathrm{SO}_{2}$ & $50{ }^{\circ} \mathrm{C}$ & $6.13 c \pm 0.52$ \\
\hline $40 \%$ Sucrose $/ 1500 \mathrm{ppm} \mathrm{SO}_{2}$ & $70{ }^{\circ} \mathrm{C}$ & $7.27 \mathrm{~d} \pm 0.41$ \\
\hline $40 \%$ Sucrose $/ 2500 \mathrm{ppm} \mathrm{SO}_{2}$ & $50{ }^{\circ} \mathrm{C}$ & $6.12 c \pm 0.41$ \\
\hline $40 \%$ Sucrose $/ 2500 \mathrm{ppm} \mathrm{SO}_{2}$ & $70{ }^{\circ} \mathrm{C}$ & $8.42 \mathrm{e} \pm 0.23$ \\
\hline $60 \%$ Sucrose $/ 1500 \mathrm{ppm} \mathrm{SO}_{2}$ & $50{ }^{\circ} \mathrm{C}$ & $5.13 b \pm 0.26$ \\
\hline $60 \%$ Sucrose $/ 1500 \mathrm{ppm} \mathrm{SO}_{2}$ & $70{ }^{\circ} \mathrm{C}$ & $7.22 \mathrm{~d} \pm 0.24$ \\
\hline $60 \%$ Sucrose $/ 2500 \mathrm{ppm} \mathrm{SO}_{2}$ & $50{ }^{\circ} \mathrm{C}$ & $6.16 c \pm 0.18$ \\
\hline $60 \%$ Sucrose $/ 2500 \mathrm{ppm} \mathrm{SO}_{2}$ & $70{ }^{\circ} \mathrm{C}$ & $8.24 \mathrm{e} \pm 0.42$ \\
\hline
\end{tabular}

Each value represents means of three replicates. Mean value having the same letter are not significantly different at $p>0.05$ )

\pm - standard deviation of the mean value. 


\section{REFERENCES}

1. Mazza G Dehydration of Carrots. Effects of Pre-drying Treatments on Moisture Transport and Product Quality. J ournal of F ood Technology 1983; 18: 113 - 23.

2. M M inn WAM and TRA Magee Physical Characteristics of Dehydrated Potatoes. J ournal of F ood Engineering 1997; 33: 49 - 55.

3. Chirife J Fundamentals of the Drying Mechanism during Air Dehydration of Foods. In: AS Mujundar (Ed). Advances in Food Dying, Hemisphere Publishing Corporation, Washington. 1985; 73 - 102.

4. Beristain $\mathrm{Cl}$, Azuara E, Cortes R and HS Garcia Mass Transfer during Osmotic Dehydration of Pineapple Rings. International Journal of Food Science and Technology 1990; 25:576 - 582.

5. Bimberet JJ, Daudin JD and E W olf Air Drying Kinetics of biological materials. In: AS Mujumdar (Ed) Advances in Drying, Hemisphere Publishing Corporation Washington. 1985; 178 - 185.

6. Lima AGB, Queiroz M R and SA Nebra Simultaneous moisture transport and shrinkage during drying of solids with ellipsoidal configuration. Chemical Engineering J ournal 2002; 86: 85-93.

7. Robbers M R, Singh P and LM Cunba Osmotic-Convective Dehydrofreezing Process for Drying Kiwi Fruit. J ournal of Food Science 1997; 62(5): 10391042.

8. Bruin S and K Luyben Drying of food materials. In: AS Mujundar (Ed). Advances in Food Dying, Hemisphere Publishing Corporation, Washington. $1985 ; 156$.

9. Rahman MS and CO Perera Drying and food preservation. In: MS Rahman (Ed). Handbook of Food Preservation, Marcel Dekker Inc. New York. 1999; 173-216.

10. K rokida $M K$ and ZB M aroulis Effect of drying method on shrinkage and porosity. Drying Technology 1997; 15 (10): 2441-2458.

11. Karim OR Effect of pre-treatment on dry kinetics and quality attributes of airdehydrated pineapple slices. An unpublished Ph.D. Thesis, University of Agriculture, Abeokuta, Ogun State, Nigeria, 2005.

12. Karim OR, Sanni LO and SO A wonorin Effect of pretreatments on quality attributes of air-dehydrated pineapple slices. J ournal of F ood Technology. 2008; 6 (45): 154-165. 
13. Alvarez CA, Aguerre R, Gomez R, Vidales $S$, Alzamora $S M$ and $L N$ Gerschenson Air Dehydration of Strawberries: Effects of Blanching and Osmotic Pretreatments on the Kinetics of Moisture Transport. J ournal of F ood Engineering 1995; 25:167 - 179.

14. K arathanos VT, K ostaropoulos AE and GD Saravacos Air Drying Kinetics of osmotically dehydrated fruits. D rying Technology 1995; 13: 1503-1521.

15. Raoult-W ack AL Osmotic Dehydration A Process with A Promising Future in Drying. In: AS Mujundar (Ed) Drying, Elsevier Science Publishers. Amsterdam, 1994.

16. Lewicki PP and HK Piechnik Computer Image Analysis of Shrinkage during Food Dehydration. In: Proceedings of the 10th International Drying Symposium, Korsakov, Poland, 30 July- 2 August, 1996; Vol. B, 293-800.

17. Vaccarezza LM , L ombadi J L and A Chrife Kinetics of Moisture Movement during Air-Drying of Sugar Beet Root. J ournal of Food Technology. 1974; 9: $317-327$.

18. AOAC. Official Methods of Analysis. 16th edition. Association of Official Analytical Chemists. Washington D. C., 1992.

19. Ghiaus AG, M argaris DP and DG Papanikas Mathematical Modeling of the Convective Drying of Fruits and Vegetables. J ournal of F ood Science 1997; 62 (6): $1154-1157$.

20. SAS. Statistical Analysis System Incorporation, United States, 2004.

21. Duncan DB Multiple range and multiple F Tests. Biometrics 1995; $11: 1$.

22. Karanthmos VT and VG Belessiotisi Sun and artificial air-drying kinetics of some agricultural products. J ournal of F ood Engineering 1997; 31: 35-46.

23. Maskan $M$ Drying, shrinkage and rehydration characteristics of kiwi fruits during hot air and microwave drying. Journal of Food Engineering 2001; 48: $177-182$.

24. Akpinar EK and $Y$ Bicer Modeling of the drying of eggplants in thin layers. International J ournal of F ood Science and Technology, 2005; 40: 273-281.

25. Spaizzi E and R M ascheroni Mass Transfer Model for Osmotic Dehydration of Fruits and Vegetables: Development of the Simulation Model. J ournal of F ood Engineering. 1997, 10: 387-410.

26. Heng W, Guilbert S and J L Cuq Osmotic dehydration of papaya: Influence of Process Variables on the Quality. Science dies Aliments 1990; 10: 83-348. 